\title{
Epizoic rotifers on Dreissena polymorpha in relation to biotic factors
}

\author{
Jolanta Ejsmont-Karabin • Maciej Karpowicz
}

Received: 23 May 2018/Revised: 15 October 2018/Accepted: 20 October 2018/Published online: 30 October 2018

(C) The Author(s) 2018

\begin{abstract}
Mollusks represent one of the most important components of freshwater zoobenthos and their shells provide a substrate for many organisms creating epibiotic communities of predominantly facultative nature. We determined rotifer species that colonize shells of Dreissena polymorpha (Pallas, 1771) without and with presence of large Cladocera and fish, alone and together. The experiment was conducted in 12 mesocosms filled with water from the littoral zone of a eutrophic lake. The experiment involved four treatments (three replicates each): (1) control of $D$. polymorpha in lake water; (2) D. polymorpha in lake water with the addition of large Cladocera; (3) $D$. polymorpha in lake water with the addition of fish; and (4) D. polymorpha in lake water with the addition of large Cladocera plus fish. The study revealed that epizoic rotifer fauna found on D. polymorpha is relatively abundant and rich in species, different from plankton communities in the same mesocosms, and
\end{abstract}

Handling editor: Checo Colón-Gaud

J. Ejsmont-Karabin ( $\square)$

Hydrobiological Station in Mikołajki, Nencki Institute of

Experimental Biology, Polish Academy of Sciences, 3

Pasteur Street, 02-093 Warsaw, Poland

e-mail: j.karabin@nencki.gov.pl

M. Karpowicz

Department of Hydrobiology, Institute of Biology,

University of Bialystok, Ciolkowskiego $1 \mathrm{~J}$,

15-245 Bialystok, Poland specific, that is, include species that prefer this habitat. It may also suggest that communities of epizoic rotifers are impacted by the presences of benthic predators, as well as by small fish and large crustaceans inhabiting littoral waters.

Keywords Mesocosms - Epibiotic Rotifera . Dreissena polymorpha $\cdot$ Eutrophic lake $\cdot$ Fish $\cdot$ Large Cladocera

\section{Introduction}

Thousands of epibiotic associations are known from marine and freshwater biocoenoses (Wahl, 1989). It seems, however, that specific and obligate epibionts are rare, and epibiosis has a predominantly facultative nature (Wahl \& Mark, 1999). Thus, an epizoic rotifer is defined here as a free or sessile animal living for at least part of its life on another animal but not disturbing the host's life. In general, the relationship between epizoic rotifers and their hosts is a neglected area of rotifer research (May, 1989; Bołtruszko, 2011). Nevertheless, there are published observations of epizoic rotifers. Ptygura melicerta Ehrenberg, 1832 was observed living in association with sponges and bivalves (Berzins, 1950; Bołtruszko, 2011; Bołtruszko \& Ejsmont-Karabin, 2013). Brachionus sessilis Varga, 1951 have been observed on different species of the cladoceran genus Diaphanosoma (Chengalath et al. 
1973), whereas Brachionus rubens Ehrenberg, 1838 inhabited different species of large Cladocera (May, 1989), which seem to be the most commonly observed hosts of epizoic rotifers. Among the species also found on their carapaces are Proales daphnicola Thompson, 1892 (Hollowday, 1949) and Brachionus variabilis (Hempel, 1896) (Ahlstrom, 1940). Species of the genus Testudinella [T. elliptica (Ehrenberg, 1834), $T$. truncata (Gosse 1886), and T. caeca (Parsons, 1892)] were found on abdominal appendages and the branchial plates of Asellus aquaticus (Linnaeus, 1758) (May, 1989; Fontaneto, \& Ambrosini, 2010). The rotifer fauna found in the branchial cavities of Astacus, Potamobius, and Cambarus include multiple species, primarily of the genus Lepadella (L. astacicola Hauer, 1926; L. borealis Harring, 1916; L. branchicola Hauer, 1926; L. lata Wiszniewski, 1939; L. parasitica Hauer, 1926) and Dicranophorus hauerianus Wiszniewski, 1939 (Koste, 1978). Bdelloid Embata parasitica (Giglioli, 1863) and monogonont T. elliptica were rotifers prevalent among species counted on ventral surfaces of Asellus aquaticus (Cook et al., 1998). Evidence for habitat selection and/or negative interactions between rotifer species epibiontic on A. aquaticus was found by Fontaneto \& Ambrosini (2010).

The list of bdelloid and monogonont epibiotic rotifer species on Gammarus pulex (Linnaeus, 1758) is also relatively long (DeSmet \& Verolet, 2016). Typically, the parasite's host is strictly limited to one species or genus. Information is lacking, however, on whether such strict relation also apply to epizoon. The fact that Ptygura spongicola Bērzinš, 1950 has been found only on sponges (Berzins, 1950; EjsmontKarabin et al., 2004), seems to indicate that we might expect such host limits for epizoic rotifers. On the other hand, epizoic communities of Rotifera on $A$. aquaticus (Cook et al., 1998) were mostly non-siteselective free-living species.

Freshwater crayfishes are also hosts to rotifer epifauna (Dražina et al., 2018). Among their specific epibionts there were four rotifer species: Lepadella astacicola, L. branchicola, L. parasitica, and Dicranophorus cambari Wulfert, 1957. Crayfish epifaunal community was highly diverse and complex, and differed significantly from surrounding fauna and periphyton.

Not much is known about epizoic rotifers on bivalves (May, 1989). Bołtruszko (2011) attempted to assess the structure of rotifer communities colonizing bivalve shells. According to the results of her studies on three relatively large species of freshwater bivalves [Anodonta anatina (Linnaeus, 1758), A. cygnea (Linnaeus, 1758), and Unio tumidus Philipsson, 1788), their epizoic fauna was found to be abundant and rich in species. They consisted of relatively common species, mostly littoral, as well as pelagic species. The number of rotifer species found on particular unionids was relatively high, but their densities were low (two to three individuals). The species of bivalves did not affect the type of epizoic rotifers observed (Bołtruszko, 2011). The epizoons of unionid mussels may be influenced by their movement behavior. They may move horizontally and burrow in sediments (Schwalb \& Pusch, 2007). In contrast, the behavior of Dreissena polymorpha (Pallas, 1771) differs, as they are sessile mussels. Thus, their epizoic community of rotifers should be less disturbed and possibly more abundant.

Dreissena polymorpha is an invasive mussel, which may change the structural complexity of bottom habitats in lakes (Ward \& Ricciardi, 2007) and positively affect the abundance of macroinvertebrates (Gergs \& Rothhaupt, 2008). However, negative impacts of $D$. polymorpha on epizoic invertebrate communities on unionids were observed in rivers (Beckett et al., 1996).

Our previous mesocosm experiments revealed that large-bodied Daphnia significantly influenced phytoplankton and zooplankton communities. Daphnia reduced algal resources, the fecundity of smallerbodied cladocerans and the density of rotifers in similar conditions (Kalinowska et al., 2015). Zoobenthos is the predominant prey of freshwater populations of ruffe, but Copepoda and Cladocera are very frequent in the diet of small fish. Although rotifers are not the preferred food for small ruffe, it is possible that they may be eaten passively together with detritus and meiobenthos (Hölker \& Thiel, 1998). Thus, both large zooplankters and small fish may have some impact on benthic (and epizoic) communities of Rotifera in shallow waters of lake littoral.

In this study, we used mesocosms filled with water from lake littoral to examine the role of overlying waters as a source of rotifer species colonizing shells of $D$. polymorpha and to evaluate the role of the presence of large Cladocera or fish in structuring of communities of rotifers epizoic on D. polymorpha. 


\section{Methods}

The experiment was carried out from June 29 to August 18, 2014 and consisted of four treatments, each replicated in triplicate. Twelve mesocosms $(0.94 \times$ $0.64 \times 0.50 \mathrm{~m} ; 300 \mathrm{~L}$, food-safe, high-density polyethylene [HDPE] containers) were filled with $270 \mathrm{~L}$ of natural water taken at a distance of $5 \mathrm{~m}$ from the shore, $1 \mathrm{~m}$ below the surface of the eutrophic Lake Mikołajskie (Masurian Lake District, north-eastern Poland; area 498 ha), and kept on the lake shore.

The set of four treatments included (1) a control consisting of $D$. polymorpha held in unfiltered lake water with small cladocerans Chydorus sphaericus (Müller, 1785), Bosmina coregoni Baird, 1857, Bosmina longirostris (Müller, 1776), Ceriodaphnia pulchella Sars 1862, and copepods Eudiaptomus gracilis (Sars, 1862), Eudiaptomus graciloides (Lilljeborg, 1888), Mesocyclops leuckarti (Claus, 1857), Thermocyclops oithonoides (Sars, 1863), and a natural set of rotifers dominated by Keratella cochlearis (Gosse, 1851), Polyarthra vulgaris Carlin, 1943, and Synchaeta kitina Rousselet, 1902 (C); (2) D. polymorpha in lake water with the addition of large Cladocera (LC); (3) D. polymorpha in lake water with the addition of fish (F); and (4) D. polymorpha in lake water with large Cladocera plus fish (LC\&F).

Dreissena polymorpha were collected from the nearby Lake Boczne, gently brushed to remove periphyton, and placed in the mesocosms. Each mesocosm had a biomass of approximately $250 \mathrm{~g} / \mathrm{m}^{2}$ wet weight. The mesocosms were devoid of sediments at the beginning of the experiment; however, some fresh sediment accumulated at the bottom by the end of the experiment.

The six mesocosms of large Cladocera (LC) consisted of two species alien to Lake Mikołajskie, that is, reared in laboratory cultures: Daphnia magna Straus, 1820 (originated from Binnensee, Germany), and Daphnia pulicaria Forbes, 1893 (originated from Lake Brome, Canada). The density of each species was 1.0 ind. $\mathrm{L}^{-1}$ at the beginning of the experiment and did not change until the end of the experiment.

Small ruffe (F), Gymnocephalus cernua (Linnaeus, 1958), were placed in $5 \mathrm{~L}$ plastic boxes with slots allowing water and plankton to pass through. The total length (longitude totalis) of fish in one mesocosm was $8.3 \pm 0.4 \mathrm{~cm}$. The fish were let out of the box for an hour to feed freely each day. The boxes were used to limit predation on zooplankton.

Samples of ten individuals of D. polymorpha and, concurrently, zooplankton from $1 \mathrm{~L}$ of mesocosm water, were taken on the last day of the experiment from each mesocosm. On the same day of the experiment, three samples of ten individuals of $D$. polymorpha were also collected from Lake Boczne. Using a soft bristle brush epizoic rotifers were removed from the shells of $D$. polymorpha collected from both mesocosms and Lake Boczne, and then treated in the same way, i.e., transferred into bottles, and fixed with Lugol's solution and then with $2 \%$ formalin. After 2-day sedimentation, the whole sediment was analyzed under the light microscope Nikon Eclipse $\mathrm{N} i$ in order to determine species structure and estimate the abundance of rotifers. The analysis showed that rotifers were not damaged.

One-liter zooplankton samples were collected after carefully mixing the water in each mesocosm on the last day of the experiment. The samples were fixed with Lugol's solution, condensed on a $30 \mu \mathrm{m}$ meshsize plankton net, and again fixed in $2 \%$ formalin.

Two indices were used:

Habitat preference index, HPI $=g-e / g+e$

where $g=$ percentage of the species numbers in total numbers of rotifers in $D$. polymorpha epizoons, and $e=$ percentage of the species numbers in total numbers of rotifers in overlying water [based on Ivlev's (1961) index].

The index of percentage similarity of community (PSC) (Whittaker \& Fairbanks, 1958):

$\mathrm{PSC}=100-0.5 \sum(a-b)=\sum \min \cdot(a, b)$

where $a$ and $b$ are percentage contributions of each species to total numbers of the community a (epizoon) and $\mathrm{b}$ (plankton), compared in pairs.

Statistical analyses were conducted with the application XLSTAT-Ecology (Addinsoft). Analysis of variance with Fisher's $F$-test was used to determine if the biotic factors significantly affect the epizoon communities. We then used Dunnett's post-hoc tests to compare means from different experimental treatments (F, LC, LC\&F) against a control group ( $D$. polymorpha in lake water). Probability levels of $\leq$ 0.05 were considered significant. The Student's $t$-test 
for one sample was used to compare the epizoon community in the experimental treatments to the zebra mussels from Lake Boczne. The nonparametric MannWhitney $U$ test was used to compare the numbers of rotifers in epizoon and plankton. Finally, Canonical Correspondence Analysis (CCA) was used to relate the rotifer communities with the experimental treatments.

\section{Results}

The density of epizoic monogononts in the experimental treatments was higher than that noted for zebra mussels from Lake Boczne $(t=4.11 ; \mathrm{p}=0.001)$, and the experimental control (Fig. 1A). The experimental treatments affected the number of epizoic monogononts $(F=16.3 ; P=0.001)$. In the treatments with large cladocerans and young fish $(\mathrm{LC}+\mathrm{F})$, the epizoon density was significantly lower than in the control $(P=$ 0.001). The lower epizoon density was also observed in the treatments with large cladocerans alone (LC) and with fish alone $(F)$, but the differences were not statistically significant.

Bdelloids were present, although in lower densities than monogononts, in all treatments. The density of epizoic bdelloids in the experimental treatments were at a level similar to that of the mussels from Lake Boczne $(t=1.62 ; P=0.067)$. The experimental treatments affected the number of epizoic bdelloids ( $F=16.3 ; P=0.001)$, similar to what was seen in monogononts. The significantly lower density of epizoic bdelloids was observed only in the experimental treatments with large cladocerans and young fish $(P=0.015)$.

In total, epizoic rotifer fauna were significantly $(P=$ $0.004)$ richer in species than planktonic rotifers in the same treatments (Table 1). The greatest difference (3.3-fold) in the number of species was found for the treatment including $D$. polymorpha, and the lowest (1.8-fold) was observed in the treatment with large cladocerans and small fish. The number of rotifer species in the experimental treatments was similar to that found on the mussels from Lake Boczne $(t=$ $-0.19 ; P=0.57)$.

Eleven species were found exclusively in the epizoons of zebra mussels. However, only four were relatively frequent, that is, noted in at least half of the studied mesocosms. These were Cephalodella eva (Gosse, 1886), Cephalodella forficula (Ehrenberg, 1832), Lecane pumila (Rousselet, 1906), and Ptygura melicerta Ehrenberg, 1832. Not one individual of the species was found in plankton in the experimental mesocosms; thus, their index of habitat preference (HPI) was 1.00 (Table 2). The three species found at $100 \%$ frequency in epizoons-Lecane closterocerca (Schmarda, 1859), Lecane lunaris (Ehrenberg, 1832), and Trichocerca relicta Donner, 1950, were also
Fig. 1 The density (indiv. per 1 mollusc) of epizoic monogononts and bdelloids in experimental mesocosms and in Lake Boczne. Explanations: $C$-control; $L C$ - with added large Cladocera; $F$-with added fish; $L C+F$-added large Cladocera plus fish
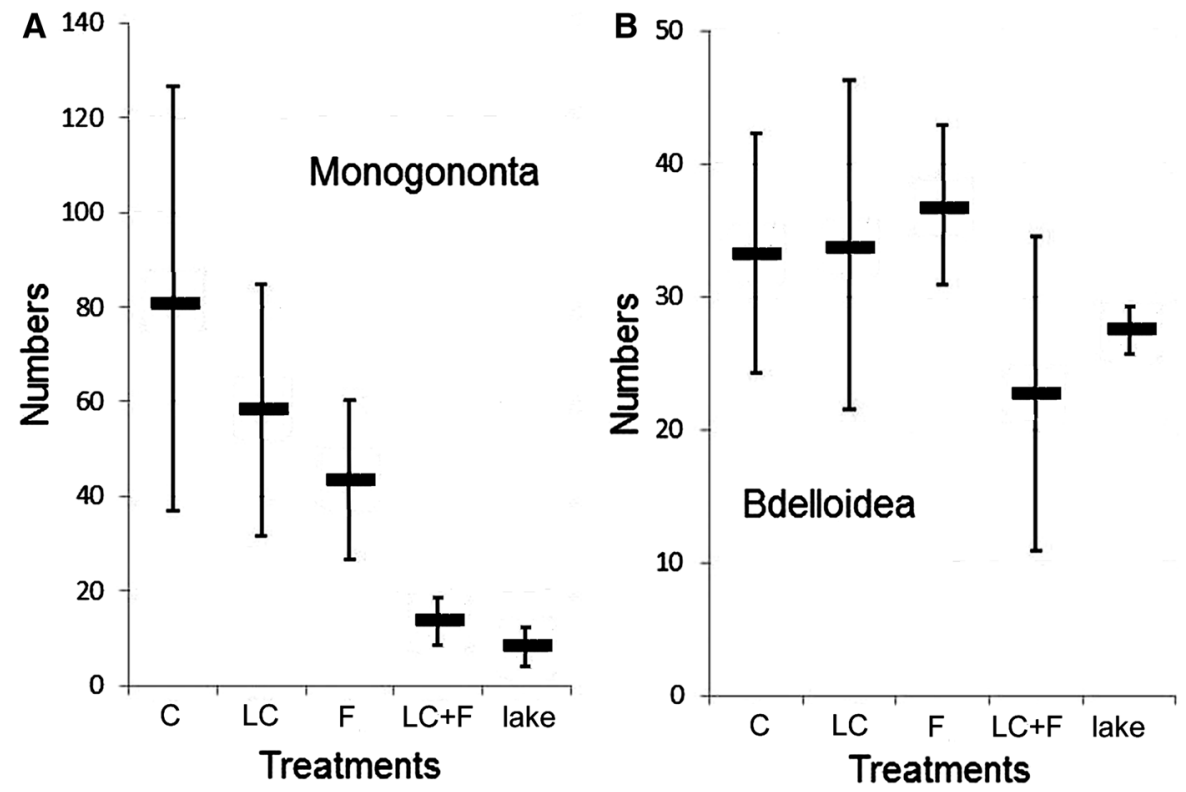
Table 1 The comparison of the total number of rotifer species met in the study mesocosms (i.e., in epizoon of Dreissena polymorpha and plankton) in different variants of the experiment

\begin{tabular}{llllll}
\hline Treatment & \multicolumn{2}{l}{ Number of species } & & & Number of species met only in \\
\cline { 2 - 3 } & Plankton & Epizoon & & Plankton & Epizoon \\
\hline In total & 26 & 51 & 5 & 30 \\
Control (C) & 9 & 30 & 31 & 2 & 23 \\
Added large Cladocera (LC) & 11 & 33 & 3 & 23 \\
Added fish (F) & 16 & 25 & 6 & 22 \\
Added large Cladocera and fish & 14 & & & 17 \\
\hline
\end{tabular}

Table 2 Mean $( \pm$ SD) values of density and the Habitat Selectivity Index and frequency in mesocosms for epizoic and plankton rotifer species. Only species with frequency $>50 \%$ were taken into account

\begin{tabular}{|c|c|c|c|c|c|c|}
\hline \multirow[t]{3}{*}{ Species } & \multicolumn{2}{|c|}{ Density in ind. $\mathrm{cm}^{-2}$} & \multicolumn{2}{|c|}{ Frequency in $\%$} & \multirow{2}{*}{\multicolumn{2}{|c|}{$\begin{array}{l}\text { Index of habitat selectivity } \\
\text { Preference for }\end{array}$}} \\
\hline & \multirow[t]{2}{*}{ Epizoon } & \multirow[t]{2}{*}{ In plankton } & \multirow[t]{2}{*}{ Epizoon } & \multirow[t]{2}{*}{ In Plankton } & & \\
\hline & & & & & Epizoon & Plankton \\
\hline Cephalodella eva (Gosse) & $0.7( \pm 0.6)$ & - & 66.7 & 0.0 & $1.0( \pm 0.0)$ & \\
\hline Cephalodella forficula (Ehrenberg) & $0.2( \pm 0.3)$ & - & 50.0 & 0.0 & $1.0( \pm 0.0)$ & \\
\hline Lecane pumila (Rousselet) & $5.4( \pm 4.2)$ & & 83.3 & 0.0 & $1.0( \pm 0.0)$ & \\
\hline Ptygura melicerta Ehrenberg & $0.3( \pm 0.3)$ & & 83.3 & 0.0 & $1.0( \pm 0.0)$ & \\
\hline Lecane luna (Muller) & $1.5( \pm 2.0)$ & $0.1( \pm 0.05)$ & 100.0 & 25.0 & $0.69( \pm 0.58)$ & \\
\hline Lecane flexilis (Gosse) & $6.6( \pm 6.0)$ & $0.1( \pm 0.05)$ & 100.0 & 50.0 & $0.64( \pm 0.48)$ & \\
\hline Lecane closterocerca (Schmarda) & $5.0( \pm 5.5)$ & $0.4( \pm 0.4)$ & 100.0 & 83.3 & $0.26( \pm 0.55)$ & \\
\hline Trichocerca relicta Donner & $0.6( \pm 0.6)$ & $0.1( \pm 0.1)$ & 100.0 & 50.0 & $0.22( \pm 0.75)$ & \\
\hline Lecane lunaris (Ehrenberg) & $2.5( \pm 1.9)$ & $0.2( \pm 0.3)$ & 100.0 & 83.3 & $0.15( \pm 0.48)$ & \\
\hline Trichocerca rattus (Muller) & $0.3( \pm 0.2)$ & $0.7( \pm 1.1)$ & 83.3 & 91.7 & & $-0.85( \pm 0.15)$ \\
\hline Polyarthra remata Skorikov & - & $0.3( \pm 0.3)$ & 0.0 & 50.0 & & $-1.0( \pm 0.0)$ \\
\hline
\end{tabular}

found in plankton. The value of HPI for the species was $0.15-0.26$, indicating a weak preference for epizoic life.

Rotifers in plankton were of extremely low density and species number in the mesocosms. Among species of high frequency in overlying waters, only one, Polyarthra remata Skorikov, 1896, occurred exclusively in plankton; its HPI was -1.0 (Table 2). The remaining plankton species also occurred in epizoons. Among those, only Trichocerca rattus (Müller, 1776) appears to prefer the open waters of the littoral zone.

The comparison of species composition of epizoic versus plankton communities in particular treatments reveals that they are $29 \%$ (mean $\pm 16 \%$ ) compatible, but there is a significant difference between treatments with and without large cladocerans and fish (Fig. 2A; $n=3 ; P=0.04)$. Thus, in the control treatment $(\mathrm{C})$, only $14.0 \%$ of the epizoic community was the same as the plankton community, whereas in the mesocosms with large cladocerans and/or fish there were more rotifers common to both epizoon and plankton (mean for the treatments $-34.0 \pm 7.4 \%$ ).

The communities from all treatments were only approximately $9 \%$ compatible with the community from Lake Boczne (Fig. 2B). The species common in the experimental communities, Cephalodella eva, $C$. gibba (Ehrenberg, 1832), C. sterea (Gosse, 1887), Lecane closterocerca, Lecane lunaris, Erignatha clastopis (Gosse, 1886), and Ptygura melicerta, were 


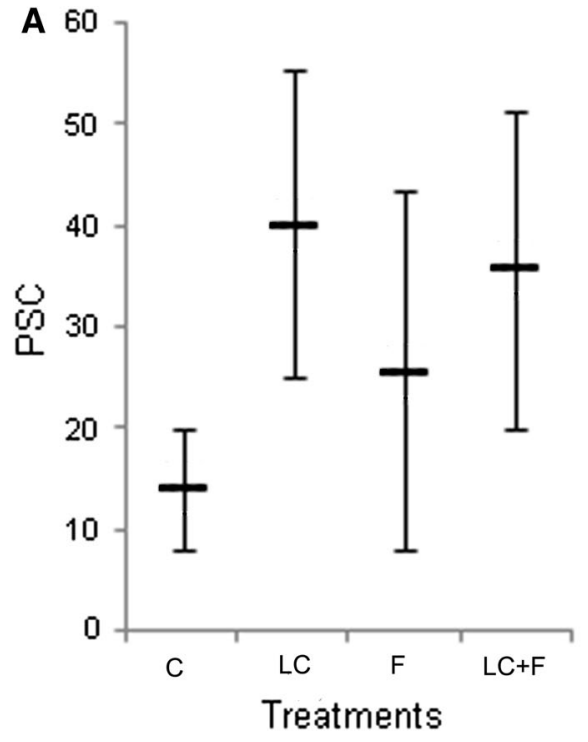

Fig. 2 The percentage similarity (PSC) of epizoic versus plankton communities in the experimental mesocosms (A) and PSC of epizoic communities in the experimental mesocosms

not abundant in the lake epizoon community, contributing to $1.2-6.2 \%$ of total rotifer density.

CCA was used to relate the rotifer communities with the treatments. The two-dimensional CCA map obtained $95.63 \%$ of the inertia, with most of it carried by the first axis (Fig. 3). The CCA results showed a strong discrepancy between the treatment with and without added crustaceans and fish. It also showed that Lecane luna (Müller, 1776), L. pumila, and L. flexilis (Gosse, 1886) are negatively correlated with both crustaceans and fish. The species diversity and originality of epizoic communities of Rotifera seem to be slightly increased by the $\mathrm{LC}+\mathrm{F}$ (large cladocerans and fish) treatment (Fig. 3).

\section{Discussion}

The study revealed surprisingly high densities and species richness of rotifer fauna occupying $D$. polymorpha shells. It also showed that the presence of competitors (large cladocerans) and predators (small fish) may indirectly influence the epizoic community of Rotifera. Plankton and littoral rotifers may escape into a zone that offers them a better hideaway. The difference between treatments with and without large cladocerans and fish highlight the role of druses of $D$.

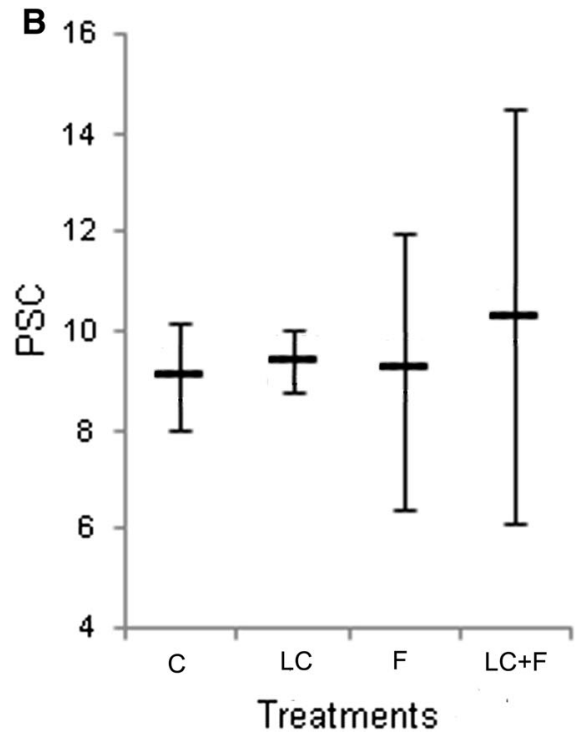

versus Dreissena's epizoon from Lake Boczne (B). Explanations: $C$-control; $L C$-with added large Cladocera; $F$-with added fish; $L C+F$-added large Cladocera plus fish

polymorpha as a refuge from suppression by crustaceans or small fish. This conclusion may be derived from the markedly higher values of percentage similarity of epizoic and plankton communities from the treatments with crustaceans and/or small fish. However, it does not explain the lower density of epizoic rotifers in the treatment with the presence of large cladocerans and fish as compared to the control. Perhaps, in habitats easily available to both cladocerans and small fish, this refuge becomes a trap. This kind of "the refuge effect" has been already observed for macrophytes, which become risky areas for zooplankton due to presence of littoral predators (Sagrario et al., 2009; Špoljar et al., 2018).

The relatively high density of epizoic monogononts in the experiment, as compared to the very low values for epizoons from the same zebra mussels from Lake Boczne, may be explained by a lack of any impact of benthic invertebrate predators in the experiment, as the mesocosms were devoid of sediments. Sediments in the littoral zone provide refuge for planktonic crustaceans (Špoljar et al., 2018) and food resources for rotifers (Ejsmont-Karabin, 2008), however they also involve predatory macroinvertebrates. High predatory pressure of macroinvertebrates on crustaceans was shown by Špoljar et al., 2018). The role of live $D$. polymorpha in creating habitats suitable for 
Fig. 3 The ordination biplot of dominant epizoic rotifers (square dots) and experimental variables obtained by CCA for four experiment treatments (round dots). Explanations: Nmon-numbers of Monogononta; Nbdellnumbers of Bdelloidea; Ngat-number of Monogononta species; $I F O$-index of faunal originality; $D$-Shannon diversity index

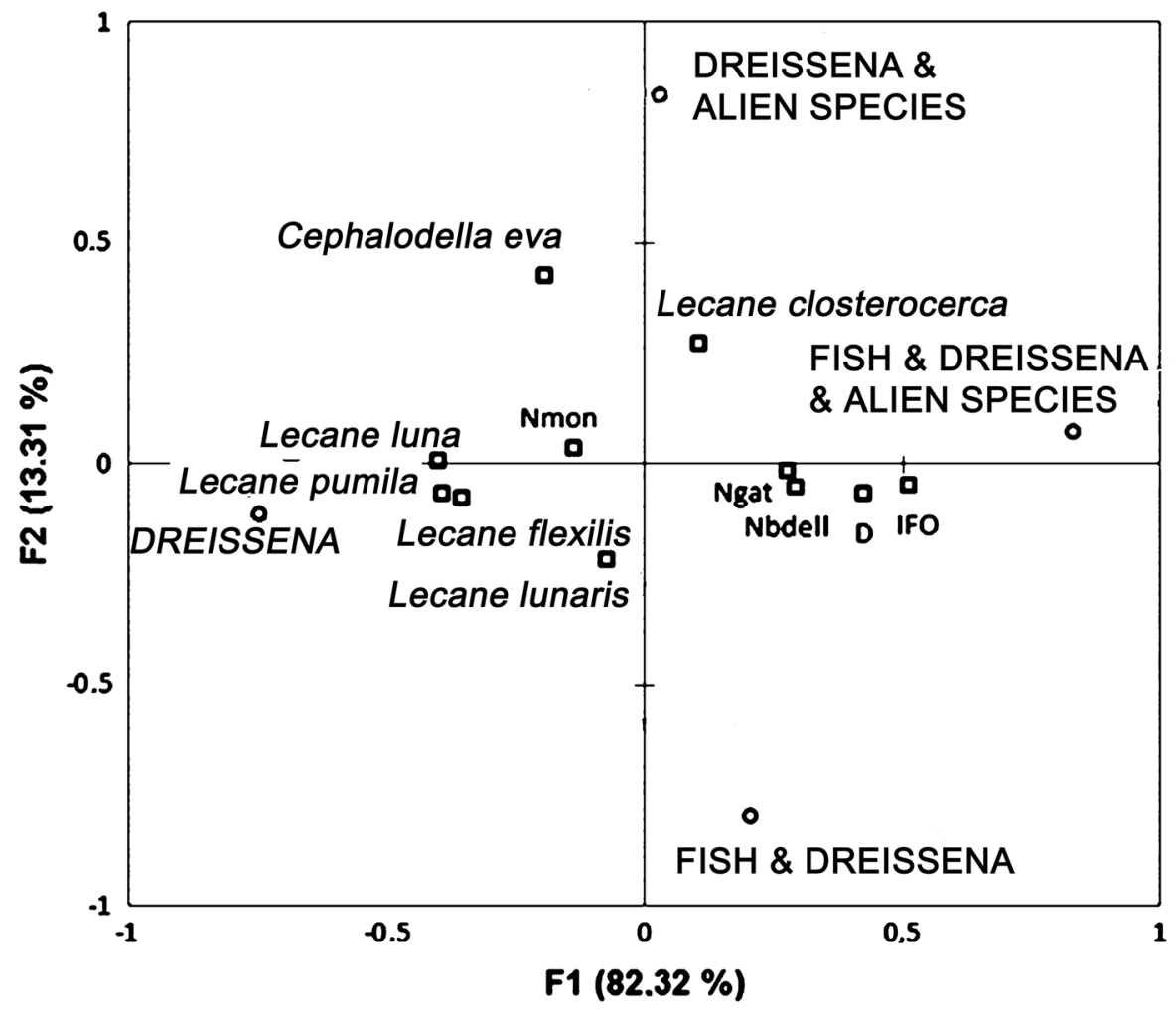

macroinvertebrates has been shown in studies by Zaiko et al. (2008) in a boreal coastal lagoon. The authors described higher benthic invertebrate biomass and species richness in zebra mussel beds when compared to other habitats. They pointed out that carnivorous species (like leeches) benefit from the easily accessible preys sheltered in druses of Dreissena.

Lack in the experimental treatments of competitors for a place, that is, other epifaunal invertebrates, may be another explanation. Studies by Bially \& MacIsaac (2000), Karatayev et al. (2002), Reed et al. (2004), and Zaiko et al. (2007) revealed that D. polymorpha a provide substrata for the epifaunal invertebrates, which normally are not able to attach to soft sediments.

The above-described lack of impact from predators and competitors on epizoic rotifers in the mesocosms may explain the much higher densities of rotifers on $D$. polymorpha shells when compared to epizoons of Anodonta and Unio (Bołtruszko, 2011). No one species from epizoons of Anodonta and Unio had a density above 1 ind. $\mathrm{cm}^{-2}$, whereas densities of dominant Lecane pumila, $L$. closterocerca, and $L$. flexilis ranged from 5.0 to 6.6 ind $\mathrm{cm}^{-2}$. Another explanation for the difference between the epizoon of unionids and $D$. polymorpha may be the movement behavior of the former, which may damage rotifers when they move horizontally and burrow in sediments (Schwalb \& Pusch, 2007). Sessile D. polymorpha probably disturb their epizoons to a lesser extent.

An unexpected phenomenon was the marked difference between the species list of epizoic rotifers in the mesocosms when compared to the communities from Lake Boczne. The percentage similarity for those communities was approximately $9-10 \%$, which means that the largest part of the experimental community was built by species absent or rare in the lake. It may suggest that the mesocosms created niches different from those found in Lake Boczne, or that a bank of "resting eggs" was different than the communities detected on bivalves from the lake.

The important role of lake shore sand deposits as the bank of resting eggs of rotifers in secondary succession has been described by Kalinowska et al. (2010). As the zebra mussel shells were thoroughly cleaned of sediment, it is possible that they were inhabited by species that hatched from eggs brought to 
mesocosms with lake water. It may suggest that even if epizoons of bivalves include species preferring this habitat, the surrounding local egg bank may have a strong impact on the community. The sediments of permanent bodies of water contain huge numbers of old and recently produced resting eggs (Duggan et al., 2002). From time to time they may undergo resuspension into the water column by currents or bioturbation (Gilbert \& Schröder, 2004).

The presence of high densities of epibiont rotifers (e.g., Brachionus rubens and Proales daphnicola) may have a negative impact on their hosts, large cladocerans (Matveeva, 1989). However, because of their small size, even very high densities of rotifers living on shells of bivalves, large-sized hosts, can hardly influence the behavior of the mollusks. The roughly estimated ratio of the average biomass of rotifers per D. polymorpha individual $(0.0016 \mathrm{mg} \mathrm{DW})$ to their host biomass (2.8 mg DW, as calculated from Nalepa et al. 1996) is ca. 1-1750.

In sum, epizoic rotifer fauna found on D. polymorpha are relatively abundant and rich in species, different from littoral plankton communities in the same mesocosms, and specific, that is, include species that prefer this habitat. Communities of epizoic rotifers appear to be impacted by the presence of benthic predators, as well as by small fish and large crustaceans inhabiting littoral waters.

Acknowledgements This research was supported by the Polish Ministry of Science and Higher Education (Project, OPUS" nr 2012/05/B/N28/02684).

Open Access This article is distributed under the terms of the Creative Commons Attribution 4.0 International License (http:// creativecommons.org/licenses/by/4.0/), which permits unrestricted use, distribution, and reproduction in any medium, provided you give appropriate credit to the original author(s) and the source, provide a link to the Creative Commons license, and indicate if changes were made.

\section{References}

Ahlstrom, E. H., 1940. A revision of the Rotatorian genera Brachionus and Platyias with descriptions of one new species and two new varieties. Bulletin of the American Museum of Natural History 77: 148-184.

Beckett, D. C., B. W. Green, S. A. Thomas \& A. C. Miller, 1996. Epizoic invertebrate communities on Upper Mississippi
River unionid bivalves. The American Midland Naturalist 135: 102-114.

Berzins, B., 1950. Observations on rotifers on sponges. Transactions of the American Microscopical Society 69: 189-193.

Bially, A. \& H. J. MacIsaac, 2000. Fouling mussels (Dreissena spp.) colonize soft sediments in Lake Erie and facilitate benthic invertebrates. Freshwater Biology 43: 85-97.

Bołtruszko, J., 2011. Epizoic communities of Rotifera on freshwater bivalves. Oceanological and Hydrobiological Studies 39: 75-82.

Bołtruszko, J. S. \& J. Ejsmont-Karabin, 2013. Epizoic communities of Rotifera inhabiting sponges in freshwaters of North-Eastern Poland. Oceanological and Hydrobiological Studies 42: 46-50.

Chengalath, R., C. H. Fernando \& W. Koste, 1973. Rotifers from Sri Lanka (Ceylon) 2. Further studies on the eurotatoria including new records. Bulletin of Fisheries Research Station, Ceylon 24: 29-62.

Cook, J. A., J. C. Chubb \& C. J. Veltkamp, 1998. Epibionts of Asellus aquaticus (L.) (Crustacea, Isopoda): an SEM study. Freshwater Biology 39: 423-438.

DeSmet, W. \& M. Verolet, 2016. Epibiotic rotifers of Gammarus pulex (L.)(Crustacea, Amphipoda), with descriptions of two new species and notes on the terminology of the trophi. Zootaxa 4107: 301-320.

Dražina, T., A. Korša, M. Špoljar, I. Maguire \& G. I. V. Klobučar, 2018. Epifauna of native and alien freshwater crayfish species (Crustacea: Decapoda): a host-specific community? Freshwater Science 37: 593-604. https://doi. org/10.1086/698764.

Duggan, I. C., J. D. Green \& R. J. Shiel, 2002. Rotifer resting egg densities in lakes of different trophic state, and their assessment using emergence and egg counts. Archiv für Hydrobiologie 153: 409-420.

Ejsmont-Karabin, J., 2008. Daily changes of the vertical microdistribution of Rotifera in lake psammolittoral. Polish Journal of Ecology 56: 717-722.

Ejsmont-Karabin, J., S. Radwan \& I. Bielańska-Grajner, 2004. Monogononta - atlas gatunków. 32B. In S. Radwan (ed), Wrotki (Rotifera). Fauna słodkowodna Polski. 32. Polskie Towarzystwo Hydrobiologiczne, Uniwersytet Łódzki. Oficyna Wydawnicza Tercja, Łódź: 147-448.

Fontaneto, D. \& R. Ambrosini, 2010. Spatial niche partitioning in epibiont rotifers on the waterlouse Asellus aquaticus. Limnology and Oceanography 55: 1327-1337.

Gergs, R. \& K. O. Rothhaupt, 2008. Effects of zebra mussels on a native amphipod and the invasive Dikerogammarus villosus: the influence of biodeposition and structural complexity. Journal of the North American Benthological Society 27 : 541-548.

Gilbert, J. J. \& T. Schröder, 2004. Rotifers from diapausing, fertilized eggs: unique features and emergence. Limnology and Oceanography 49: 1341-1354.

Hölker, F. \& R. Thiel, 1998. Biology of ruffe (Gymnocephalus cernuus (L.))-a review of selected aspects from European literature. Journal of Great Lakes Research 24: 186-204.

Hollowday, E. D., 1949. Introduction to the study of the Rotifera-IX Proales daphnicola Thompson: with reference to commensal and parasitic habits. The Microscope 6: 1-7. 
Ivlev, V. S., 1961. Experimental ecology of the feeding of fishes. Yale University Press, New Haven: 302.

Kalinowska, K., J. Ejsmont-Karabin \& J. I. Rybak, 2010. The role of lake shore sand deposits as bank of ciliate, rotifer and crustacean resting forms: experimental approach. Polish Journal of Ecology 58: 323-332.

Kalinowska, K., J. Ejsmont-Karabin, M. Rzepecki, I. Kostrzewska-Szlakowska, I Yu Feniova, A. Palash \& A. R. Dzialowski, 2015. Impacts of large-bodied crustaceans on the microbial loop. Hydrobiologia 744: 115-125.

Karatayev, A. Y., L. E. Burlakova \& D. K. Padilla, 2002. Impacts of zebra mussels on aquatic communities and their role as ecosystem engineers. In Leppäkoski, E., S. Gollasch $\&$ S. Olenin (eds.), Invasive aquatic species of Europedistribution, impact and management. Kluwer, Dordrecht: 433-446.

Koste, W., 1978. Rotatoria. Bortraeger, Berlin, 2 Vol. 673 pp.

Matveeva, L. K., 1989. Interelations of rotifers with predatory and herbivorous Cladocera: a review of Russian works. Hydrobiologia 186(187): 69-73.

May, L., 1989. Epizoic and parasitic rotifers. Hydrobiologia 186(187): 59-67.

Nalepa, T. F., D. J. Hartson, G. W. Gostenik, D. L. Fanslow \& G. A. Lang, 1996. Changes in the freshwater mussel community of Lake St. Clair: from Unionidae to Dreissena polymorpha in eight years. Journal of Great Lakes Research 22: 354-369.

Reed, T., S. J. Wielgus, A. K. Barnes, J. J. Schiefelbein \& A. L. Fettes, 2004. Refugia and local controls: benthic invertebrate dynamics in Lower Green Bay, Lake Michigan following zebra mussel invasion. Journal of Great Lakes Research 30: 390-396.
Sagrario, G., M. de los Angeles, E. Balseiro, R. Ituarte \& E. Spivak, 2009. Macrophytes as refuge or risky area for zooplankton: a balance set by littoral predacious macroinvertebrates. Freshwater Biology 54: 1042-1053.

Schwalb, A. N. \& M. T. Pusch, 2007. Horizontal and vertical movements of unionid mussels in a lowland river. Journal of the North American Benthological Society 26: 261-272.

Špoljar, M., T. Dražina, J. Lajtner, M. Duić Sertić, I. Radanović, R. Wallace, D. Matulić \& T. Tomljanović, 2018. Zooplankton assemblage in four temperate shallow waterbodies in association with habitat heterogeneity and alternative states. Limnologica 71: 51-61.

Wahl, M., 1989. Marine epibiosis. I. Fouling and antifouling: some basic aspects. Marine Ecology Progress Series 58: 175-189.

Wahl, M. \& O. Mark, 1999. The predominantly facultative nature of epibiosis: experimental and observational evidence. Marine Ecology Progress Series 187: 59-66.

Ward, J. M. \& A. Ricciardi, 2007. Impacts of Dreissena invasions on benthic macroinvertebrate communities: a metaanalysis. Diversity and Distributions 13: 155-165.

Whittaker, R. H. \& C. W. Fairbanks, 1958. A study of plankton copepod communities in the Columbia Basin, Southeastern Washington. Ecology 39: 46-65.

Zaiko, A., S. Olenin, D. Daunys \& T. Nalepa, 2007. Vulnerability of benthic habitats to the aquatic invasive species. Biological Invasions 9: 703-714.

Zaiko, A., D. Daunys \& S. Olenin, 2008. Habitat engineering by the invasive zebra mussel Dreissena polymorpha (Pallas) in a boreal coastal lagoon: impact on biodiversity. Helgoland Marine Research 63: 85-94. 